\title{
Asthma Exacerbations in the Pediatric Emergency Department at a Tertiary Hospital: Association With Environmental Factors
}

\author{
Marques-Mejías MA'1 Tomás-Pérez $\mathrm{M}^{1,2}$, Hernández I', López I', Quirce $\mathrm{S}^{1,2,3}$ \\ 'Department of Allergy, Hospital Universitario La Paz, Madrid, Spain \\ 2Department of Allergy, Hospital La Paz Institute for Health Research (IDIPAZ), Madrid, Spain \\ ${ }^{3} \mathrm{CIBER}$ de Enfermedades Respiratorias CIBERES, Madrid, Spain
}

J Investig Allergol Clin Immunol 2019; Vol. 29(5): 365-370

doi: 10.18176/jiaci.0364

\begin{abstract}
Introduction: Children with asthma experience recurrent respiratory symptoms and exacerbations due to multiple environmental factors. The aim of this study was to describe the prevalence and triggers of asthma exacerbations and their management in a cohort of pediatric patients attended in an emergency department (ED).

Methods: We performed an observational, retrospective, single-center study in the pediatric ED of Hospital Universitario La Paz, Madrid, Spain in 2015. Children with asthma exacerbations attending the ED were included after a thorough search using our institutional computer database. Pollen and atmospheric mold spore counts and pollution data were collected for that period from official websites. Multiple logistic regression was used to assess the association between daily pollution ( $\mathrm{NO}_{2}, \mathrm{PM}_{10}$, ozone, pollen, and molds) and admissions to the ED because of asthma.

Results: During 2015, a total of 50619 patients were attended in the ED of our hospital. Of these, 2609 (5\%) were diagnosed with asthma exacerbation/bronchospasm. The patient had to be admitted to hospital in $21.7 \%$ of cases. The main triggers of asthma exacerbations were respiratory infection in 1841 cases (70.6\%). A significant correlation was found between grass pollen counts and ED admissions $(P<.0001)$. A positive correlation was also found between $\mathrm{ED}$ admissions and $\mathrm{NO}_{2} 0.58(95 \% \mathrm{Cl}, 0.02-0.87)$ and $\mathrm{PM}_{10} 0.75(95 \% \mathrm{Cl}$, $0.31-0.93)(P<.05)$

Conclusion: Environmental factors such as grass pollen counts and pollution $\left(\mathrm{NO}_{2}\right.$ and $\left.\mathrm{PM}_{10}\right)$ are associated with a higher frequency of admission to the ED.
\end{abstract}

Key words: Pediatric asthma. Asthma exacerbations. Air pollutants. Asthma management.

\section{Resumen}

Introducción: Los niños con asma presentan síntomas respiratorios y exacerbaciones recurrentes debido a múltiples factores ambientales. El objetivo de este estudio es describir la prevalencia y los desencadenantes de las exacerbaciones del asma y su manejo en una cohorte de pacientes pediátricos atendidos en un servicio de urgencias (SU).

Métodos: Se trata de un estudio observacional, retrospectivo, unicéntrico, dirigido en urgencias pediátricas del Hospital Universitario La Paz (Madrid, España) en 2015. Los pacientes con diagnóstico de exacerbación de asma fueron seleccionados a partir de una búsqueda informática. La información referente a niveles de pólenes, hongos y contaminación fue recogida en portales digitales oficiales. Se realizó una regresión logística múltiple para evaluar la asociación entre la contaminación diaria (determinada por los niveles $\mathrm{NO}_{2}, \mathrm{PM}_{10}, \mathrm{O}$, recuentos de polen y hongos) y las admisiones por asma en el SU.

Resultados: En el 2015 fueron atendidos en urgencias pediátricas de nuestro hospital 50.619 niños. De estos, 2.609 (5\%) tenían diagnóstico de exacerbación asmática/broncoespasmo. El 21,7\% de los casos requirió ingreso. Los principales desencadenantes fueron las infecciones $(70,6 \%)$. La relación entre picos de polinización de gramíneas y admisión en urgencias fue significativa $\left(p<10^{-4}\right)$. Igualmente una correlación positiva fue obtenida entre ingresos en el SU y NO$~_{2} 0,58\left(95 \% 0,02\right.$ a 0,87) y $\mathrm{PM}_{10} 0,75(95 \% 0,31$ a 0,93$)(\mathrm{p}<0,05)$. Conclusión: Factores ambientales como el recuento de polen de gramíneas y partículas contaminantes $\left(\mathrm{NO}_{2}, \mathrm{PM}_{10}\right)$ se asocian con un mayor número de episodios de broncoespasmo atendidos en urgencias.

Palabras clave: Asma pediátrica. Exacerbaciones del asma. Contaminantes ambientales. Manejo de asma. 


\section{Introduction}

The prevalence of asthma among children in the European Union is currently estimated to be $9.4 \%$ [1]. The incidence of the disease continues to increase around the world [2], generating a considerable economic burden through direct and indirect costs in developed countries. A large part of the costs is related to emergency department (ED) care and hospitalization $[3,4]$. In Spain, asthma exacerbation episodes account for $5 \%$ of pediatric ED visits, which may reach $10 \%$ $15 \%$ at certain times of the year $[5,6]$.

An asthma exacerbation can be defined as an increase in airway inflammation that causes airflow limitation and triggers asthma symptoms (wheezing, shortness of breath, coughing, and chest tightness). It can be considered severe if it requires systemic corticosteroids and/or ED care or hospitalization $[7,8]$.

Children are more susceptible than adults to the negative health effects of pollutants $[9,10]$. In many cohorts, a positive association has been demonstrated between exposure to pollutants and mild to severe asthma exacerbations and has been directly linked to reduced lung function [7,9-11].

The air pollutants most frequently associated with severe exacerbations are daily levels of nitrogen dioxide $\left(\mathrm{NO}_{2}\right)$, fine particulate matter measuring $10 \mu \mathrm{m}$ or less in diameter $\left(\mathrm{PM}_{10}\right)[12,13]$, ozone, and airborne pollen [14]. The relationship between asthma exacerbation and factors such as allergic inflammation, infection, and pollution remains unclear [15].

The aim of this study was to describe the prevalence of episodes of asthma exacerbation and their management in a cohort of pediatric patients attended in an ED in Madrid, Spain. Secondary analyses were performed to predict potential triggers. We report on management of ED admissions for asthma in the largest pediatric cohort analyzed to date. We also examine the association between asthma exacerbations and environmental factors in Spain during the last 10 years.

\section{Material and Methods}

We performed an observational, retrospective, singlecenter study in the pediatric ED of Hospital Universitario La Paz, Madrid, Spain from January 1 to December 31, 2015. We performed a computerized search for patients based on the key words difficulty breathing, wheezing, and/or dyspnea. Those with a diagnosis of asthma exacerbation were enrolled in the study. Data on each visit were collected from the ED computer system and hospital medical records. The variables included were sex, age, treatment received in the ED, need for hospitalization, month of the year of admission, probable cause of symptoms, and referral to the allergy or pneumology department. Information on allergy tests performed during the follow-up visits was obtained from the medical records of the pediatric allergy department.

Pollen and mold spore counts were collected for the study period from the Aerobiology Committee of the Spanish Allergy and Clinical Immunology (SEAIC) website (https:// www.polenes.com/home). Environmental pollution data were retrieved from the website of the air quality section of
Madrid City Council (http://www.mambiente.munimadrid. es/opencms/opencms/calaire). Air pollutants $\left(\mathrm{NO}_{2}\right.$ and $\left.\mathrm{PM}_{10}\right)$ were monitored from Plaza Castilla station, one of the main stations in the city $(2.7 \mathrm{~km}$ from the hospital). We calculated the mean daily, weekly, and monthly count during that period. For pollen and mold data, the mean monthly concentrations of Gramineae, Cupressaceae, and Olea europaea were recorded in grains per cubic meter $\left(\mathrm{g} / \mathrm{m}^{3}\right)$; the concentration of Alternaria alternata was recorded in spores per cubic meter.

\section{Statistical Analysis}

The analysis was based on descriptive statistics. Continuous variables were expressed as median (IQR), and categorical variables were expressed as frequency and percentage. ANOVA or the Wilcoxon rank-sum test was used to identify differences between groups for continuous variables. The Pearson $\chi^{2}$ test was used to analyze categorical variables. Multiple logistic regression was used to assess the association between daily pollution $\left(\mathrm{NO}_{2}, \mathrm{PM}_{10}\right.$, and ozone) and admission to the ED because of asthma. The independent variables were levels of air pollutants $\left(\mathrm{NO}_{2}, \mathrm{PM}_{10}\right.$, and ozone), pollen, and molds. Admission to the ED was considered the dependent variable. Statistical significance was set at $P<.05$. All the analyses were performed using SPSS R version 3.4.3, platform: x86_64w64-mingw32/x64 (64-bit), running under Windows $10 \times 64$ (build 16299).

This study was approved in its initial version by the Ethics Committee of Hospital Universitario La Paz (code HULP: PI-2347).

\section{Results}

During 2015, a total of 50619 patients were attended in the ED of our hospital. Of these, 2609 (5\%) were diagnosed with asthma exacerbation/bronchospasm. The distribution by sex was 1534 boys $(58.8 \%)$ and 1075 girls $(41.2 \%)(P<.0001)$. The children included were between 0 and 15 years old, with a mean (SD) age of 3.59 (3.11) years.

Most cases resolved with outpatient care $(78.3 \%)$, while $21.7 \%$ required admission to hospital. The mean age of admitted patients was $3.2(2.87)$ years. Two or more episodes were registered in $607.8(23.3 \%)$ patients, 23 of whom $(0.9 \%)$ had experienced 6-8 episodes during that year. The number of recurrent episodes is shown by month of the year in the Table.

The most commonly used treatment was short-acting $\beta_{2}$-agonists in $85.1 \%$ of cases, followed by systemic corticosteroids in $54.7 \%$. Inhaled corticosteroids were used in $1.8 \%$, and other treatments such as anticholinergics, oxygen, and antipyretics were used in $41.7 \%$ of the sample. Up to $10.8 \%$ of the patients did not receive any treatment in the ED owing to absence of symptoms during the medical assessment and/or previous medication at home or in other health centers.

The main triggers of exacerbations were infections in 1841 cases $(70.6 \%)$, followed by unknown factors in $748(28.7 \%)$. The remaining possible causes were cutaneous exposure to allergens $(0.6 \%)$ and food allergy $(0.1 \%)$. Although there was no systematic microbiological confirmation of suspected respiratory infections, most were believed to be secondary 
Table. Number of Recurrent Asthma Exacerbation Episodes in Children That Attended the Emergency Department at Hospital Universitario La Paz During 2015

\begin{tabular}{lcc} 
Month & $\begin{array}{c}\text { No. of Recurrent } \\
\text { Episodes }\end{array}$ & $\%$ \\
\hline January & 76 & 10.7 \\
February & 50 & 7.0 \\
March & 58 & 8.1 \\
April & 69 & 9.7 \\
May & 88 & 12.3 \\
June & 40 & 5.6 \\
July & 14 & 2.0 \\
August & 9 & 1.3 \\
September & 62 & 8.7 \\
October & 107 & 15.0 \\
November & 86 & 12.1 \\
December & 54 & 7.6 \\
\hline
\end{tabular}

to viruses according to epidemiological data and clinical characteristics.

During 2015, the highest number of patients attended for asthma exacerbations was registered in December, November, May, and October in descending order $(P<.0001)$. The highest percentage of patients being followed in allergy departments and attended in the ED was registered in May (34.1\%) followed by February (29.2\%) and April (28.6\%). The difference between these percentages and those recorded during the rest of the year was statistically significant $(P<.0001)$ (Figure 1$)$.

A total of 596 out of $2609(22.8 \%)$ patients were evaluated in allergy departments. The most prevalent sensitizer in these
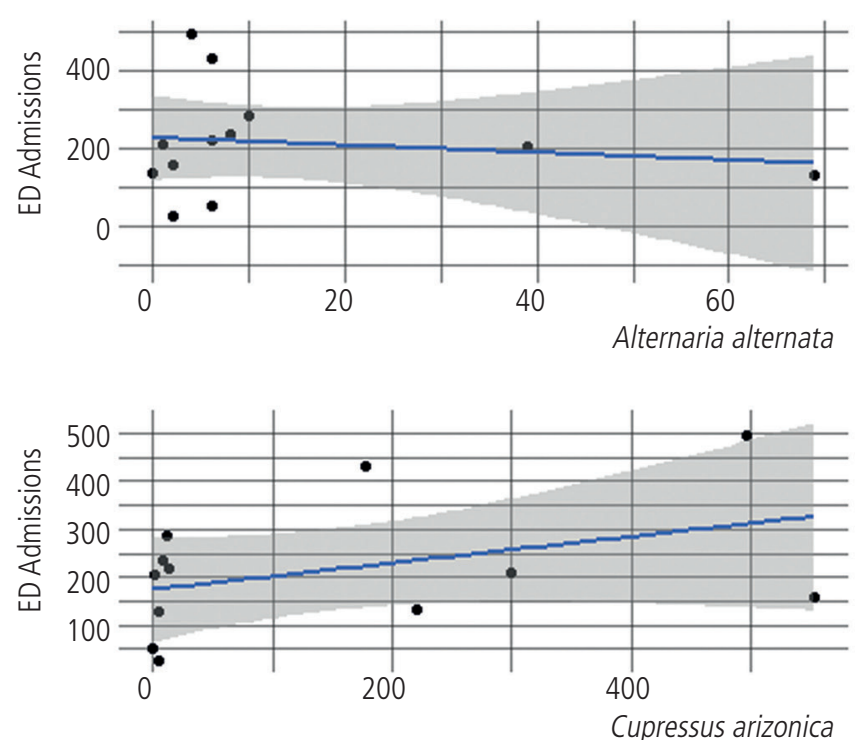

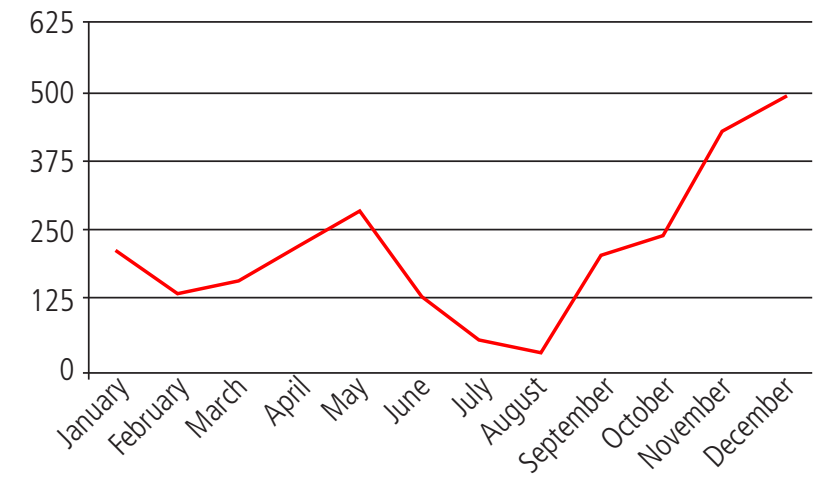

— Number of episodes

Figure 1. Number of patients with asthma exacerbations who attended the emergency department during 2015.

children was pollen $(275 / 596$ [46.1\%]), followed by animal dander (136/596 [22.8\%]), molds (61/596 [10.2\%]), and house dust mite (39/596 [6.5\%]). No sensitization was found at the time of evaluation in $14.3 \%$ of the sample.

A statistically significant $(P<.0001)$ relationship was found between grass pollen counts and ED admissions, whereas no correlation was found between ED admissions and counts of other pollens (Cupressus arizonica, Olea europaea) and molds (Alternaria alternata) (Figure 2).

A positive correlation was found between admission to the ED and $\mathrm{NO}_{2} 0.58(95 \% \mathrm{CI}, 0.02-0.87)$ and $\mathrm{PM}_{10} 0.751$ (95\%CI, 0.31-0.93). Assessment of these air pollutants based on a linear regression model reinforced these findings (Figure $2)$. A weak negative correlation was found between ozone and ED admissions $(-0.67$ [95\% CI, -0.9 to -0.17$]$ ) (Figure 3 ).

We further analyzed the effect of environmental factors by dividing our sample into 3 groups: (1) Children aged 0-3 years, who presented a weak but significant positive correlation
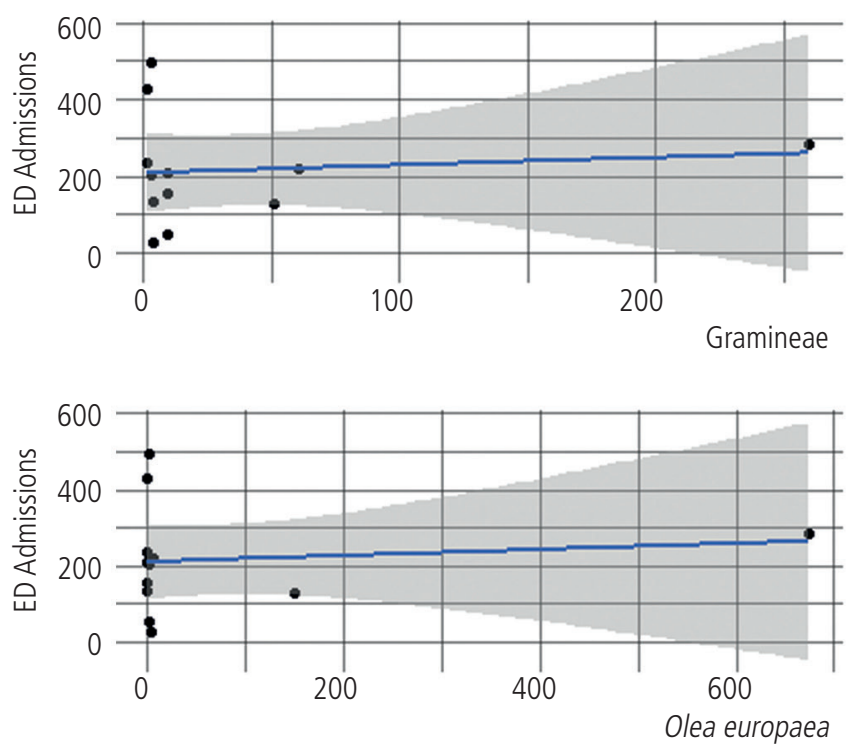

Figure 2. Correlation between pollens (Gramineae, Cupressus arizonica, Olea europaea), Alternaria alternata, and admissions to the emergency department. 

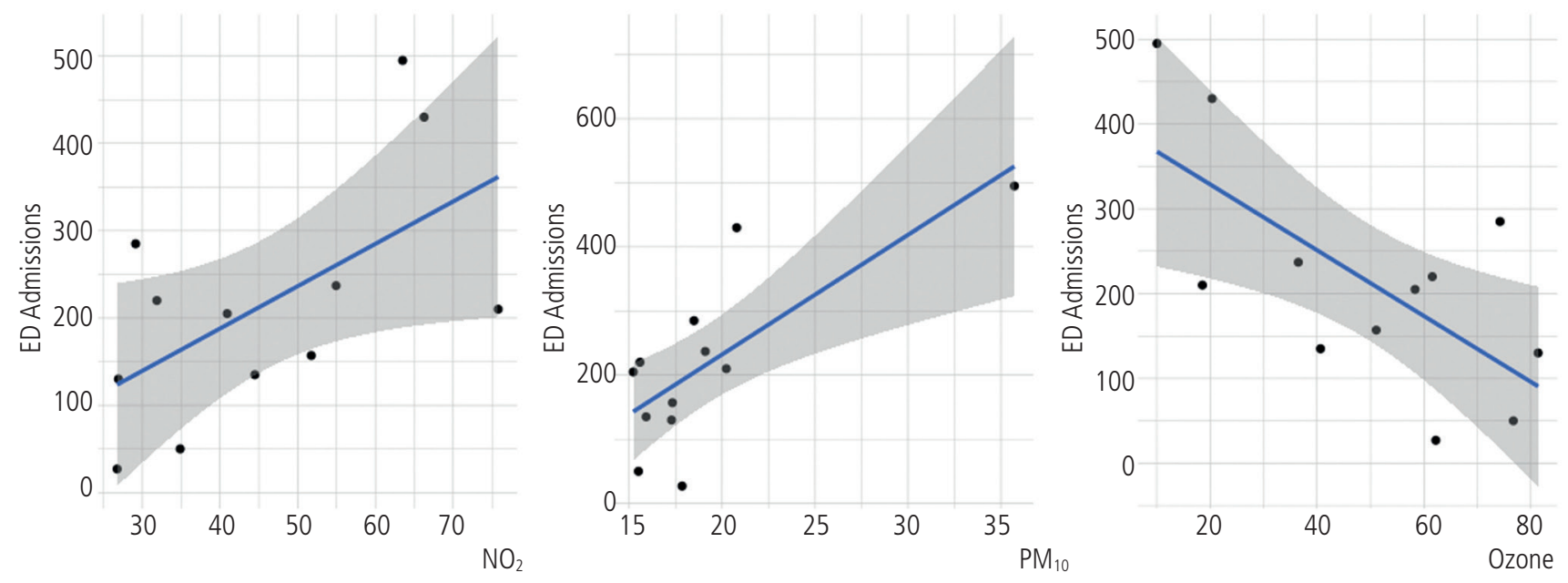

Figure 3. Correlation between air pollutants $\left(\mathrm{NO}_{2}, \mathrm{PM}_{10}\right.$, ozone $)$ and admission to the emergency department.

between $\mathrm{ED}$ admissions and $\mathrm{PM}_{10}(0.028)$ and grass pollen counts (0.02); (2) Children aged 4-7 years, who also presented a weak correlation between ED admissions and $\mathrm{PM}_{10}(0.034)$ grass pollen counts $(0.01)$; (3) Children aged 8-14 years, who were affected by $\mathrm{PM}_{10}, \mathrm{NO}_{2}$, and ozone. We found a significant positive correlation between them $\left(\mathrm{PM}_{10}\right.$ [0.060], ozone [0.027], $\mathrm{NO}_{2}$ [0.029]). Regarding pollen counts, there was a significant though weak correlation between ED admissions and Cupressaceae and grass pollen counts (0.011).

In more than half of the patient population, there was no recorded follow-up by either the allergy or the pneumology department $(57.6 \%)$. Up to $11.1 \%$ of the patients were followed up in allergy departments, $20 \%$ in pneumology departments, and $11.2 \%$ in both. Of the admitted patients, $50.7 \%$ had regular check-up visits by specialists (allergist or pneumologist). Of this percentage, $22.9 \%$ were followed up by an allergist only.

\section{Discussion}

The increase in hospital admissions for wheezing or asthma attacks is a growing health care problem in developed countries, generating considerable costs for health systems $[4,16]$. Since 2016, after the Melbourne thunderstorm asthma study, specialists around the world have been paying more attention to ED admissions in order to detect high-risk populations [17]. In this sense, children continue to be a vulnerable population during these types of episodes.

The treatment of asthma exacerbations is complex, since many patients continue to have asthma-related symptoms at home once they have been discharged from the ED [18]. The rising frequency of asthma exacerbations indicates that management of the disease continues to be suboptimal [18-21].

In our sample, more than $20 \%$ of the children had more than 1 asthma exacerbation in 1 year, thus reinforcing the importance of regular check-ups and adjustment of regular controller treatment in these patients. Adjustments should be based on the triggers involved in the exacerbations, the medical history, and the response to treatment in the ED.
One of the current hypotheses for the origin and persistence of wheeze in children involves the interactions between inflammatory pathways triggered by exposure to aeroallergens and respiratory pathogens that hamper the normal development of the airway tissues $[22,23]$. These changes can lead to phenotypic alterations that probably predispose to subsequent development of persistent wheeze [22,23]. This theory proposes that the risk for development of persistent wheeze and asthma is amplified if early sensitization is accompanied by severe lower respiratory tract infections during the first years of life [3,24].

As for infections that affect children, the prevalence of respiratory syncytial virus (RSV) in the pediatric population is estimated to be around 50\% during the first year of life [25]. Sigurs [26] investigated the relationship between RSV and asthma and reported a statistically significant increase in asthma frequency in 47 children with RSV compared with a control group. Across the world, most RSV outbreaks are during early spring, fall, and winter [9]. More than $70 \%$ of asthma exacerbations attended in our hospital over 1 year are due to infections. While our findings are similar (mean age of the sample, 3 years; highest percentage of asthma exacerbations in the months of December, November, May, and October), microbiological confirmation is needed in further cohorts to clarify the origin of the infections [26].

The biological effects of pollutants and other air contaminants such as pollen and mold spores are enhanced in children because of the immaturity of the immune system and physiological characteristics such as low body weight and higher respiratory frequency [27-29]. The latter leads children to inhale greater amounts of pollutants, with subsequent inflammation of the smaller airways [28-29], which can be worsened by concurrent factors, such as infection or air pollutant peaks during pollination seasons.

The effect of air pollution on the airway varies according to the molecular weight of the particles. $\mathrm{NO}_{2}, \mathrm{PM}_{10}$, and ozone particles have been linked to adverse effects in the airways [17,30,31]. In our study, we found a significant correlation between $\mathrm{NO}_{2}$ and $\mathrm{PM}_{10}$ and bronchospasm. 
Furthermore, it has been suggested that the effect of $\mathrm{PM}_{10}$ depends mainly on particles measuring less than $2.5 \mu \mathrm{m}$, because they can remain in the atmosphere for longer periods and can access the respiratory tract easier than larger ones [31]. Ozone is responsible for an almost $10 \%$ increase in the risk of ED visits, especially in children aged 6-19 years [17]. Although we could not find strong correlations, the group most susceptible to ozone was that comprising children aged 8-15 years. This finding is consistent with previous reports [17]. For the total population, we found an inverse correlation, probably because of other factors that affect the pediatric population or because the values were obtained using different sampling devices.

The relationship we found between air pollutants and pediatric admissions to the ED in the scatterplots is similar to those obtained in other cohorts in Spain [32-33].

In industrialized countries, the prevalence of sensitization to pollen has increased in recent decades, probably owing to the interaction between pollen grains and air pollutants mainly in large cities [30,34]. Pollen concentrations have been linked to increases in the frequency of ED visits. In Madrid, data from 3 cohorts have demonstrated this association in the past 20 years $[14,35,36]$. Our results confirm the importance of grass pollen allergens as relevant triggers of asthma attacks during springtime, particularly as pollination peaks in May (34\% of allergic patients were attended in the ED owing to exacerbations during this month). This percentage probably underestimates the number of sensitized patients attending the ED because of the low percentage of referrals to our unit $(22.3 \%$ in total).

Interestingly, we did not find any correlation between ED admissions and the other pollen families analyzed (Cupressus arizonica, Olea europaea) or molds (Alternaria alternata). Further investigations must be designed to seek alternative explanations for these findings.

One of the main limitations when studying asthma in the pediatric population is the lack of objective diagnostic tools, with the result that the diagnosis is usually based on clinical data. Because this is a retrospective study, some elements of the ED visits may not have been recorded thoroughly, such as classification of the episodes by severity. Moreover, follow-up of these patients needs to be appropriate in order to clearly assess the probable causes of multiple exacerbations.

Data regarding pollutants were extracted using 2 different measurement sites-Plaza Castilla Station $\left(\mathrm{NO}_{2}, \mathrm{PM}_{10}\right)$ and Barrio El Pilar station (ozone) - and the actual address of the patients was not registered. Both stations covered living areas considered for this analysis. However, since we do not know the distance from patients' homes and the measurement tools used, we cannot estimate individual data for exposure to pollutants. This might also explain the differences between data for our sample and previously published data.

Our study was conducted in one of the largest pediatric EDs in Madrid. Therefore, it seems reasonable to assume that a 1-year sample of care in this type of pediatric ED can be extrapolated to other tertiary hospitals. However, the same results probably cannot be generalized to smaller health care institutions, not only because of the heterogeneity of treatment protocols, but also because of the expected variability in terms of exposure to air pollutants. Individual data should also be recorded regarding exposure to irritants such as smoke.
Despite the limitations of this observational retrospective study, our results highlight the complex interaction between the multiple factors that can affect asthma in the pediatric population. In addition, this large-scale study stresses the need for a multidisciplinary approach in the follow-up of pediatric patients with asthma exacerbations.

\section{Acknowledgments}

The authors are grateful to José Delgado $\mathrm{PhD}$ for his support and work in the statistical analysis of the sample.

\section{Funding}

The authors declare that no funding was received for the present study.

\section{Conflicts of Interest}

The authors declare that they have no conflicts of interest.

\section{References}

1. Selroos O, Kupczyk M, Kuna P, Lacwik P, Bousquet J, Brennan $D$, et al. National and regional asthma programmes in Europe. Eur Respir Rev. 2015;24:474-83.

2. KonéAJ, Rivard M, Laurier C. Impact of follow-up by the primary care or specialist physician on pediatric asthma outcomes after an emergency department visit: the case of Montreal, Canada. Pediatr Asthma Allergy Immunol. 2007;20:23-35.

3. Wang LY, Zhong Wheeler L. Direct and indirect costs of asthma in school-age children. Prev Chronic Dis. 2005;2:11.

4. Gergen, PJ. Understanding the economic burden of asthma. J Allergy Clin Immunol. 2001:107:445-85.

5. Mintegui Raso S, Benito Fernández J, González-Balenciaga $\mathrm{M}$, Landluce $\mathrm{A}$. Consequences of the strength treatment of children with asthma in pediatric emergency department on to in hospital admission. Emergencias. 2003;15:345-50.

6. Ballestero Y, De Pedro J, Portillo N, Martínez-Mugica O, AranaArri E, Benito J. Pilot Clinical Trial of High-Flow Oxygen Therapy in Children with Asthma in the Emer-gency Service. J Pediatr. 2018;204-10

7. O'Connor GT, Neas L, Vaughn B, Kattan M, Mitchell H, Crain $E$, et al. Acute res-piratory health effects of air pollution on children with asthma in US inner cities. J Allergy Clin Immunol. 2008; 121:1133-9.

8. Samoli E, Nastos PT, Paliatsos AG, Katsouyanni K, Priftis KN. Acute effects of air pollution on pediatric asthma exacerbation: Evidence of association and effect modifica-tion. Environ Res. 2011;111:418-24

9. Burbank A, Peden D. Assessing the impact of air pollution on childhood asthma morbidity: how, when, and what to do. Curr Opin Allergy Clin Immunol. 2018;18:124-31.

10. Tétrault LF, Doucet $M$, Gamache $P$, Fournier $M$, Brand $A$, Kosatsky T, et al. Severe and Moderate Asthma Exacerbations in Asthmatic Children and Exposure to Ambient Air Pollutants. Int J Environ Res Public Health. 2016;13:771.

11. Just J, Ségala C, Sahraoui F, Priol G, Grimfeld A, Neukirch F. Short-term health effects of particulate and photochemical air pollution in asthmatic children. Eur Respir J. 2002;20:899906. 
12. Peel JL, Tolbert P, Klein M, Busico K, Flanders D, Todd K, et al. Ambient air pollu-tion and respiratory emergency department visits. Epidemiology. 2005;16:164-74.

13. Sunyer, J, Spix C, Quenel P, Ponce-de-León A, Pönka A, Barumandzadeh $\mathrm{T}$, et al. Urban air pollution and emergency admissions for asthma in four European cities: the APHEA project. Thorax. 1997; 52:760-5.

14. Galán I, Prieto A, Rubio M, Herrero T, Cervigón P, Cantero JL, et al. Association between airborne pollen and epidemic asthma in Madrid, Spain: a case-control study. Thorax. 2010;65:398-402.

15. Heymann P, Carper H, Murphy D, Platts-Mills T, Patrie J, McLaughlin A, et al. Vi-ral infections in relation to age, atopy and season of admission among children hospitalized for wheezing. J Allergy Clin Immunol. 2004;114:239-46.

16. Loyano P, Sullivan SD, Smith DH, Weiss KB. The economic burden of asthma in US children: estimates from the National Medical Expenditure Survey. J Allergy Clin Immunol. 1999; 104; 957-63.

17. D'Amato G, Annesi-Maesano I, Cecchi L, D'Amato M. Latest news on relationship between thunderstorms and respiratory allergy, severe asthma, and deaths for asthma. Allergy. 2019;74(1):9-11.

18. Stempel DA, Roberts CS, Stanford RH. Treatment patterns in the months prior to and after asthma-related emergency department visit. Chest. 2004;126:75-80.

19. Quirce S, Delgado J, Entrenas LM, Grande M, Llorente C, López $A$, et al. Quality indicators of asthma care derived from the Spanish Guidelines for Asthma Management (GEMA 4.0): A Multi-disciplinary team report. J Investig Allergol Clin Immunol. 2017;27:69-73.

20. Pola-Bibian B, Domínguez-Ortega J, Vilá-Nadal G, Entrala A, González Cavero L, Barranco $P$, et al. Asthma exacerbations in a tertiary hospital: Clinical features, triggers and risk factors for hospitalization. J Investig Allergol Clin Immunol. 2017;27:238-45.

21. Akinbami LJ, Moorman JE, Bailey C, Zaharan HS, King $M_{\text {, }}$ Johnson CA, et al. Trends in asthma prevalence health care use, and mortality in the United States, 2001-2010. NCHS Data Brief, 2012;94:1-8.

22. Sporik R, Holgate ST, Cogswell JJ. Natural history of asthma in childhood: a birth cohort study. Arch Dis Child, 1991;66:1050-3.

23. Wiesch D, Meyers D, Bleeker E. Genetics of asthma. J Allergy Clin Immunol. 1999;104:895-901.

24. Toni D, Terry Y. Respiratory syncytial virus. Pediatr Rev.1998;19:55-61.

25. Sigurs N, Bjarnason R, Sigurbergsson F, Kjellman B. Respiratory syncytial virus bronchiolitis in infancy is an important risk factor for asthma and allergy at age 7. Am J Respir Crit Care Med. 2000;161:1501-7.
26. Sigurs, N. A cohort of children hospitalized with acute RSV bronchiolitis: impact on later respiratory disease. Paediatr Respir Rev. 2002;3:177-83.

27. EPAs Office of environmental Health Hazards Assessment and the American Lung Association of California. Air pollution and children's health. A fact sheet. California, USA, 2003.

28. Díaz J, Linares C, Tobías A. Short-term effects of pollen species on hospital ad-missions in the city of Madrid in terms of specific causes and age. Aerobiologia 2007;23:231-8.

29. Bouazza N, Foissac F, Urien S, Guedj R, Carbajal R, Tréluyer JM, et al. Fine par-ticulate pollution and asthma exacerbations. Arch Dis Child. 2017;0:1-4.

30. D'Amato M, Cecchi L, Annesi-Maesano I, D'Amato G. News on Climate Change, Air Pollution, and Allergic Triggers of Asthma. J Invest Allergol Clin Immunol. 2018;28:91-7.

31. Diaz J, García R, Ribera P. Modelling of air pollution and its relationship with mor-tality and morbidity in Madrid, Spain. Int Arch Occup Environ Health 1999;72:366-76.

32. Pablo-Romero M, Román R, González Limón JM, PraenaCrespo M. Effects of fine particles on children's hospital admissions for respiratory health in Seville, Spain. J Air Waste Manag Assoc. 2015;65:436-44.

33. Klinnert M, Nelson $H$, Price $M$, Adinoff A, Leung D, Mrazek D. Onset and persis-tence of Childhood Asthma: Predictors from infancy. Pediatrics, 2001;108:69.

34. D'Amato, G. Enviromental urban factors (air pollution and allergens) and the rising trends in allergic respiratory diseases. Allergy. 2002;57:30-3.

35. Tobías A, Galán I, Banegas JR. Short-term effects of airborne pollen concentrations on asthma epidemic. Thorax. 2003:58:708-10.

36. Linares C, Díaz J, Tobías A, De Miguel JM, Otero A. Impact of urban air pollutants and noise levels over daily hospital admissions in children in Madrid: a time series analysis. Int Arch Occup Environ Health. 2006;79:14352.

\section{Manuscript received June 8, 2018; accepted for publication December 11, 2018.}

\section{- M Andreína Marques-Mejías}

Department of Allergy

Hospital Universitario La Paz

Paseo de la Castellana, 261

Madrid, Spain

E-mail: mandreina.marques@gmail.com 